\title{
Indirect Costs of Rheumatoid Arthritis Depending on Type of Treatment-A Systematic Literature Review
}

\author{
Bogdan Batko ${ }^{1}$ * , Paulina Rolska-Wójcik ${ }^{2}$ and Magdalena Władysiuk ${ }^{2}$ \\ 1 Department of Rheumatology, J. Dietl Specialist Hospital, Skarbowa 1 St, 31-121 Cracow, Poland \\ 2 HTA Consulting, Starowislna 17/3 St, 31-038 Cracow, Poland \\ * Correspondence: bpbatko@gmail.com; Tel.: +48-665-366-766
}

Received: 21 July 2019; Accepted: 15 August 2019; Published: 17 August 2019

\begin{abstract}
The economic burden of rheumatoid arthritis (RA) on society is high. Disease-modifying antirheumatic drugs (DMARDs) are the cornerstone of therapy. Biological DMARDs are reported to prevent disability and improve quality of life, thus reducing indirect RA costs. We systematically reviewed studies on the relationship between RA and indirect costs comparing biological treatment with standard care. Studies, economic analyses, and systematic reviews published until October 2018 through a MEDLINE search were included. A total of 153 non-duplicate citations were identified, $92(60 \%)$ were excluded as they did not meet pre-defined inclusion criteria. Sixty-one articles were included, 17 of them (28\%) were reviews. After full-text review, 28 articles were included, 11 of them were reviews. Costs associated with productivity loss are substantial; in several cases, they may represent over $50 \%$ of the total. The most common method of estimation is the Human Capital method. However, certain heterogeneity is observed in the method of estimating, as well as in the resultant figures. Data from included trials indicate that biological therapy is associated with improved labor force participation despite an illness, in which the natural course of disease is defined by progressive work impairment. Use of biological DMARDs may lead to significant indirect cost benefits to society.
\end{abstract}

Keywords: rheumatoid arthritis; productivity loss; workplace; absenteeism; cost of illness; economic burden; indirect cost; presenteeism; sick leave; systematic review

\section{Introduction}

Rheumatoid arthritis (RA) is a progressive, chronic autoimmune disease that carries a significant global burden and affects economic activity [1,2]. Progressive joint damage, pain, disability, and premature mortality are hallmarks of RA, particularly if not treated early and appropriately [3]. Environmental and socioeconomic factors may also influence disease status [4]. Patients often suffer from symptoms that may be objectively difficult to quantify (e.g., fatigue), while they impact work performance, and are often disregarded by employers [5]. Close to a third of patients may be permanently work disabled within the first three years of disease, which leads to both societal and individual costs [6]. In 1992, health and social care direct costs were estimated at over $£ 600$ million in the United Kingdom (UK), with indirect costs (lost productivity) estimated at an additional £651million [7]. An estimate of the annual economic burden of RA in the United States (US) puts the societal impact at \$19.3 billion (in 2005), with 56\% ( $\$ 10.9$ billion) due to indirect costs [8]. The introduction of new treatment strategies and biological agents in the last 20 years, for which clinical results indicate declining physical disability rates, is revolutionary [9]. The economic question long debated is whether greater efficacy justifies its higher costs [10]. With increased understanding of pathogenesis, novel therapies are emerging, however, many are still limited to experimental settings, and conventional synthetic disease modifying anti-rheumatic drugs along with biological agents remain the mainstay of therapy [11]. In this respect, it is worth 
mentioning that people with RA are recommended to use a wide variety of self-management methods. The purpose of implementing these programs is reducing pain and inflammation, reducing the risk of deformities developing, and maintaining or improving function [12].

Costs of illness can usually be divided into the more tangible direct costs, e.g., healthcare expenditures associated with treatment and management, and indirect costs related to productivity loss [13]. The latter can be valued through either the human capital method (HCM) or friction cost method (FCM) [14]. HCM is based on a societal perspective of future productivity, in which an individual's lack of contribution to society is projected, carrying the assumption of employee irreplaceability [13]. Conversely, the FCM assesses productivity loss until an individual is replaced [15]. High disease-related costs of RA for the individual, healthcare system and society have been previously assessed by cost-of-illness studies in numerous countries $[16,17]$. Studies have shown that presenteeism reduces work productivity to a greater extent than absenteeism, and is considered the largest component of work productivity loss [18,19]. In chronic conditions, including arthritis, presenteeism is regarded as a major contributor to costs [19-21]. Comprehensive data on the impact of biological agents on indirect costs are limited. Previous estimates may not be relevant to the current era of biological therapy.

This literature review examines the relationship between the economic aspects of biological therapy on absenteeism, and on presenteeism, and it provides an overview of indirect costs of absenteeism and presenteeism in RA patients treated with biological therapies. It should be noted that our search strategy is prone to a degree of bias, owing to the adoption of several brand names for biological agents, which may lead to incomplete retrieval of records, as e.g., some agents may be restricted in certain countries.

\section{Materials and Methods}

We performed a systematic literature review aimed to identify studies or economic evaluations relevant to indirect costs in RA patients treated with biological agents (Table A1). Studies, analyses, and reviews on RA economic topics published until October 2018 through MEDLINE literature database search were examined. Search results were screened in title relevance and full-text copies were retrieved if a publication was an article, which fulfilled the following criteria: (i) subjects at or over the age of 18, with a diagnosis of RA, (ii) a comparison of any type of biological therapy with any kind of treatment was performed, (iii) a measure of productivity loss was a study outcome, (iv) or the article was a narrative or systematic review of such studies, and (v) it was in English language. In the search strategy the authors adopted several brand names for biological agents. We excluded duplicate reports. This process was conducted by two readers and is summarized in Figure 1. Studies were evaluated in a three-step process; title list consideration, evaluation of abstracts that passed the latter step and finally, articles that were of relevance were reviewed. Disagreement between the two reviewers was resolved by consensus of a third party. Data from eligible primary studies of indirect RA costs were extracted into abstraction forms and a spreadsheet was used for data entry. Productivity was investigated with a focus on two different measures: presenteeism, which is synonymous with work limitation, and absenteeism, or time off work due to RA [18].

We screened 153 non-duplicate citations (last update: 2 October 2018), 92 of which (60\%) were excluded as they did not meet pre-defined inclusion criteria. Sixty-one articles were included, 17 of which $(28 \%)$ were reviews. After full-text review, 28 articles were included, 11 of them were reviews. Exclusion reasons: no information about indirect costs in case of biological and non-biological therapies (24), publication in Chinese language (3), only company perspective (1), direct and indirect costs presented together (2), the amount of indirect costs based on the level of the original publication included in this analysis (4). The selection process is presented in the PRISMA diagram (Figure 1). 


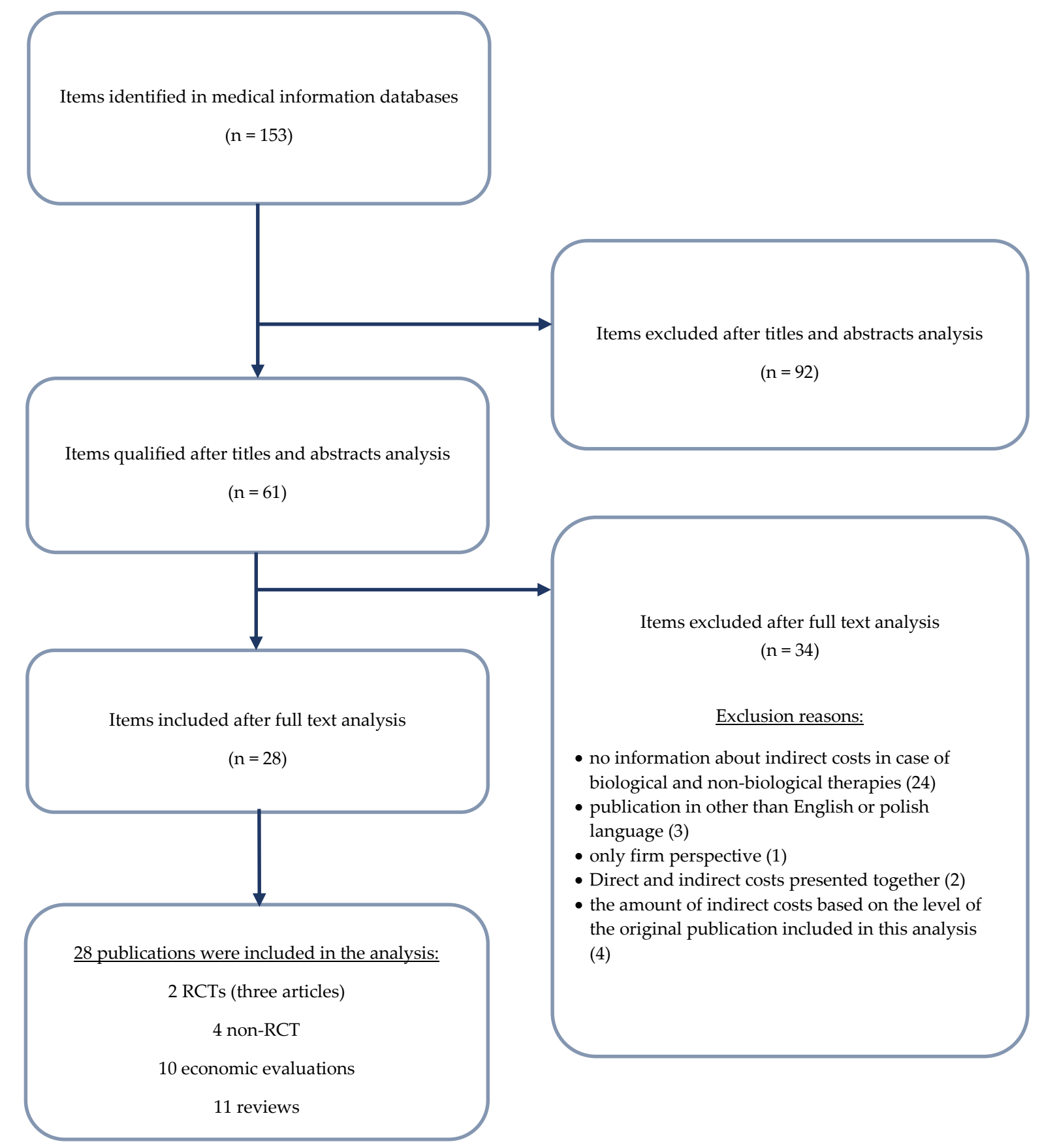

Figure 1. Scheme of selection of clinical trials found in the systematic review in accordance with PRISMA.

\section{Results}

Two of identified studies were randomized controlled trials (RCT) (three articles) [22-24], four were observational studies/registry or cross-sectional in design [25-28], and 10 of them were economic evaluations [29-38]. Eleven reviews were included in the review and described in the discussion section [14,24,38-46]. Risk of bias in RCTs and observational trials included in systematic review were assessed (details in appendix) using the modified Cochrane Collaboration tool to assess risk of bias for randomized controlled trials and National Institute for Health and Care Excellence (NICE) scale to assess the risk of bias in observational trials [47,48].

Most of studies estimated the indirect costs using the human capital method $[23,24,26,28]$, two of them the friction cost method [22,27], and one of them did not report the method [25]. Measures of 
work productivity loss (while at work) due to presenteeism were the Work Limitations Questionnaire (WLQ) [23], the Work Productivity and Activity Impairment Questionnaire (WPAI) [23], the Work Ability Index (WAI), and Health and Labor Questionnaire (HLQ) [24]. Although all measures were developed to measure presenteeism, they vary in construct, recall period, attribution, and reference frame, as previously discussed [46]. Indirect costs due to absenteeism are often calculated as the number of hours or days absent multiplied by average pay rate [23], with HCM being the preferred method. As actual salary data are not always available, the mean salaries of corporations, and mean or median wages (overall or by age and gender) are often used as a surrogate for actual wages. In included studies the source for productivity loss information was patient self-report [23]. Data were collected via a questionnaire completed at the clinic [23]. With few exceptions, the patients were identified via a physician diagnosis of RA, usually according to American College of Rheumatology or American Rheumatology Association criteria (ACR) [22-24]. Functional disability was measured according to the scale of Health Assessment Questionnaire (HAQ) [22-24].

Evidence from studies in the literature suggests that treatment with the tumor necrosis factor (TNF) inhibitors etanercept $[23,25,26]$, adalimumab $[24,25,28]$, and infliximab (IFX) $[22,25]$ increases productivity, and reduces the degree of RA-related absenteeism and presenteeism.

\subsection{Absenteeism and Presenteeism}

For the studies fulfilling the criteria of our review we provide an overview of design, patient population, and comparator (Table 1), and outcome measures for indirect costs with respective monetary gains associated with improved absenteeism (Tables 1 and 2) and presenteeism (Tables 1 and 3). Risk of bias was also assessed (Tables A2 and A3). Studies are also summarized below.

The COMET (COmbination of Methotrexate and ETanercept) trial was a 2-year double-blind randomized clinical trial. In a sub-analysis provided by Anis et al., the impact of etanercept (ETA) addition to methotrexate (MTX) on productivity outcomes was evaluated during the first year in MTX naïve, early RA patients. Absenteeism was an outcome, assessed through the number of stopped and missed work days, and reduced working time in patients who were working at baseline, as reported by them in questionnaires. Outcomes were recorded at four visits during follow-up, but patients in part/fulltime work with at least one visit were included. The recall period was 4 and 8 weeks between the first two and latter two visits. Due to a lack of exact data for the dates of work stoppage/renewal, two scenarios for maximum and minimum absenteeism were constructed, however, they remain reliant on some assumptions. Patients treated with ETA + MTX vs. MTX were reported with 18 fewer missed work days (95\% CI: 2, 34). Total absenteeism was significantly improved under both scenarios, with 37 fewer work days lost at maximum (95\% CI: 6; 68), and 22 for minimum scenario (95\% CI: 2; 43). Presenteeism was not directly assessed in the COMET trial and had to be indirectly imputed from a sensitivity analysis for base estimates for absenteeism. Potential limitations in the calculation of presenteeism have to be addressed; presenteeism estimates may vary with part-time workers who may devote more time to self-care, while the method of presenteeism imputation from absenteeism may result in collinearity and inflate the analyses. Independent of chosen measure, productivity loss measures in MTX-treated patients were generally higher than with combination therapy. However, the magnitude seems to depend on the mode of measure [23]. 
Table 1. Methodology of trials about the effect of biological treatment on absenteeism and presenteeism.

\begin{tabular}{|c|c|c|c|c|c|c|c|c|c|c|}
\hline Author & Study Design & Treatment & $n$ & Stage of RA & $\begin{array}{c}\text { Age } \\
\text { Range } \\
\text { (Mean) }\end{array}$ & $\begin{array}{l}\text { Disease } \\
\text { Duration } \\
\text { (Mean) }\end{array}$ & $\begin{array}{l}\text { Absenteeism } \\
\text { Measure }\end{array}$ & Presenteeism Measure & Method & Time Points \\
\hline & & & & & RCT Trial & & & & & \\
\hline \multirow{4}{*}{ Allaart 2007 [22] } & \multirow{4}{*}{ RCT (BeST) } & 1. Seq. monotherapy & \multirow{4}{*}{508} & \multirow{4}{*}{ Early RA (ACR criteria) } & \multirow{4}{*}{$\geq 18(\mathrm{ND})$} & \multirow{4}{*}{ ND } & \multirow{4}{*}{$\begin{array}{l}\text { Three-monthly diary } \\
\text { on work absenteeism }\end{array}$} & \multirow{4}{*}{ - } & \multirow{4}{*}{ FCM } & \multirow{4}{*}{ Baseline until 2 years } \\
\hline & & 2. Step-up comb. Therapy $(\mathrm{INF})^{\mathrm{c}}$ & & & & & & & & \\
\hline & & 3. Initial comb. Therapy $(\mathrm{INF})^{\mathrm{d}}$ & & & & & & & & \\
\hline & & 4. $\mathrm{MTX}+\mathrm{INF}^{\mathrm{d}}$ & & & & & & & & \\
\hline \multirow[t]{3}{*}{ Anis 2009 [23] } & \multirow[t]{2}{*}{ RCT (COMET) } & MTX & 100 & \multirow[t]{2}{*}{ Early RA (ACR criteria) } & $\geq 18(45.1)$ & 8.9 months & $\begin{array}{c}\text { Number of missed } \\
\text { work days/WPAI }\end{array}$ & \multirow[t]{2}{*}{ Reduced working time (in days)/WLQ } & \multirow[t]{2}{*}{ НСм } & \multirow{2}{*}{$\begin{array}{l}0 \text { and } 12 \text { months } \\
\text { (weeks 12, 24, 36, 52) }\end{array}$} \\
\hline & & ETA + MTX & 105 & & $\geq 18(45.4)$ & 8.6 months & $\begin{array}{c}\text { Number of stopped } \\
\text { work days } \mathrm{s}^{\mathrm{f}} / \mathrm{WLQ}\end{array}$ & & & \\
\hline & \multicolumn{10}{|c|}{ Observational Studies } \\
\hline Zhang 2008 [24] & $\begin{array}{l}\text { Open-label, multicenter, phase IIIb study } \\
\text { (CanAct) }\end{array}$ & $\mathrm{ADA}$ & 389 & $\begin{array}{l}\text { Moderate to severe active RA } \\
\text { (ACR criteria) }\end{array}$ & (55.0) & 12.5 years & $\begin{array}{l}\text { Number of absent } \\
\text { work days multiplied } \\
\text { by the individual's } \\
\text { daily wage }\end{array}$ & $\begin{array}{l}\text { Number of extra work hours patients needed } \\
\text { to cath up on tasks they were } \\
\text { unable to complete during normal working } \\
\text { hours multiplied by the individual's } \\
\text { hourly wage }\end{array}$ & HСм & $\begin{array}{l}\text { Baseline and } 12 \\
\text { months }\end{array}$ \\
\hline $\begin{array}{l}\text { Augustsson } \\
2010[25]\end{array}$ & Observational (STURE register) & Anti-TNF (ETA, INF, ADA) & 594 & ND & $\begin{array}{l}18-55 \\
\text { years } \\
(40.0)\end{array}$ & 9.4 years & - & Hours worked/week & ND & $\begin{array}{l}\text { Baseline, } 6 \text { months, } 1 \\
2,3,4 \text {, and } 5 \text { years }\end{array}$ \\
\hline Hone 2013 [26] & Prospective, observational study & ETA & 204 & Moderate to severe RA & $\begin{array}{l}20-67 \\
(46.6)\end{array}$ & 5.1 years & $\begin{array}{l}\text { WPAI measures of } \\
\text { absenteeism-work } \\
\text { time missed }\end{array}$ & $\begin{array}{l}\text { WPAI measures of presenteeism - impairment } \\
\text { at } \\
\text { work }\end{array}$ & HCM & 6 months \\
\hline \multirow[t]{3}{*}{ Klimes 2014 [27] } & \multirow[t]{3}{*}{$\begin{array}{l}\text { Bottom-up cross-sectional cost-of-illness } \\
\text { study }\end{array}$} & Without biologics & 137 & \multirow[t]{3}{*}{ ND } & $\begin{array}{l}18-64 \\
\text { years } \\
(58.9) \\
\end{array}$ & 13.6 years & \multirow{3}{*}{$\begin{array}{c}\text { Days spent on sick } \\
\text { leave, and the period } \\
\text { of time spent on full } \\
\text { disability pension or } \\
\text { partial disability } \\
\text { pension }\end{array}$} & \multirow[t]{3}{*}{ - } & \multirow[t]{3}{*}{ FCM } & \multirow[t]{3}{*}{6 months } \\
\hline & & With biologics & 124 & & $\begin{array}{l}18-64 \\
\text { years } \\
(53.6)\end{array}$ & 15.5 years & & & & \\
\hline & & DMARDs & 130 & & (53.7) & 10.1 months & & & & \\
\hline Tanaka 2018 [28] & $\begin{array}{l}\text { Non-interventional trial for up-verified } \\
\text { effects and utility (ANOUVEAU) study }\end{array}$ & $\mathrm{ADA}^{\mathrm{i}}$ & $\begin{array}{c}1 \\
196\end{array}$ & $\begin{array}{l}\text { Greater portion of the patients had } \\
\text { established } \\
\text { RA, with moderate disease activity }\end{array}$ & PW: $(50.0)$ & 5.6 years & $\begin{array}{l}\text { WPAI measures of } \\
\text { absenteeism-work } \\
\text { time missed }\end{array}$ & $\begin{array}{l}\text { WPAI measures of presenteeism-impairment } \\
\text { at } \\
\text { work }\end{array}$ & НСм & 48 weeks \\
\hline
\end{tabular}

CZP—certolizumab pegol, ADA—adalimumab, DMARD—disease modifying antirheumatic agent, ETA—etanercept, IFX—infliximab, MTX—methotrexate, RCT —randomized clinical trial, ND—no data, NA—not applicable, OWI—overall work impairment, AI-activity impairment, RTX—rituximab, PW—paid worker employed for $\geq 35 \mathrm{~h} /$ week; PTW—part time worker employed for <35 h/week; HM —home maker non-employed; HCM—human capital method, FCM—friction cost method; ACR—American College of Rheumatology; RA—rheumatoid arthritis; WPAWork Productivity and Activity Impairment; (a) to be eligible for treatment with infliximab or etanercept, patients had to have a diagnosis of RA according to clinical judgment and have failed to respond to, or to be intolerant of, at least two DMARDs, including methotrexate; (b) MTX, next steps sulfasalazine, leflunomide, MTX + infliximab, gold, MTX + cyclosporine + prednisone, azathioprine + prednisone; (c) MTX, next steps add sulfasalazine, then hydroxychloroquine, then prednisone, next switch to MTX + infliximab, MTX + cyclosporine + prednisone, leflunomide, gold, azathioprine + prednisone; (d) starting with MTX + sulfasalazine + a tapered high dose of prednisone, next step MTX + cyclosporine + prednisone, next MTX + infliximab, leflunomide, gold, azathioprine + prednisone; (e) starting with MTX + infliximab, next steps sulfasalazine, eflunomide, MTX + cyclosporine + ( pred ( $\mathrm{ADA}$ ) as stated in the current Japanese labelling recommendations for ADA and met the Japanese guidelines issued by the Japan College of Rheumatology for the use of TNF inhibitors 
Table 2. Effect of biological treatment on absenteeism studies.

\begin{tabular}{|c|c|c|c|c|c|c|c|}
\hline Author & Measure & Comparator & Difference & $\Delta$ & $95 \%$ CI & Significant or Not & Costs \\
\hline \multicolumn{8}{|c|}{ RCT Trials } \\
\hline \multirow{4}{*}{ Anis 2009 [23] } & Missed work days & \multirow{4}{*}{$\begin{array}{l}\text { MTX vs. } \\
\text { ETA+MTX }\end{array}$} & 31.9 vs. 14.2 & -17.6 & $(-34.4 ;-2.2)$ & YES & $-£ 1244^{\mathrm{c}, \mathrm{f}}$ \\
\hline & Reduced working time & & 19.8 vs. 10.5 & -9.3 & $(-21.9 ; 3.9)$ & NO & $-£ 657^{c, f}$ \\
\hline & Stopped worked days & & $\begin{array}{l}\text { Scenario Ic: } 32.9 \text { vs.10.9 } \\
\text { Scenario IId: } 12.3 \text { vs. } 4.8\end{array}$ & $\begin{array}{l}-22.1 \\
-7.4\end{array}$ & $\begin{array}{l}(-45.2 ;-0.3) \\
(-15.9 ; 1.2)\end{array}$ & $\begin{array}{l}\text { YES } \\
\text { NO }\end{array}$ & $\begin{array}{l}\text { Scenario I: }-£ 1562^{\mathrm{c}, \mathrm{d}, \mathrm{f}} \\
\text { Scenario II: }-£ 523^{\mathrm{c}, \mathrm{e}, \mathrm{f}}\end{array}$ \\
\hline & Total absenteeism & & $\begin{array}{l}\text { Scenario Ic: } 65.6 \text { vs. } 29.0 \\
\text { Scenario IId: } 44.3 \text { vs. } 22.3\end{array}$ & $\begin{array}{l}-36.6 \\
-22.0\end{array}$ & $\begin{array}{l}(-68.3 ;-5.9) \\
(-42.6 ;-2.1)\end{array}$ & $\begin{array}{l}\text { YES } \\
\text { YES }\end{array}$ & $\begin{array}{l}\text { Scenario I: }-£ 2586^{\mathrm{c}, \mathrm{d}, \mathrm{f}} \\
\text { Scenario II: }-£ 1555^{\mathrm{c}, \mathrm{e}, \mathrm{f}}\end{array}$ \\
\hline \multirow[t]{2}{*}{ Allaart 2007 [21] } & \multicolumn{2}{|c|}{ Overall } & $\begin{array}{r}\text { Decrease of } 0.1 \text { on utility as } \\
\text { working }\end{array}$ & $\begin{array}{l}\text { ociated } \\
\mathrm{h} / \text { week }\end{array}$ & th decrease of 2 & \multirow{2}{*}{\multicolumn{2}{|c|}{$\begin{array}{l}\text { Using the friction-cost method, overall societal costs were estimated at } € 19,905, € 15,926 \\
€ 17,810 \text {, and } € 28,547 \text { ( } p \leq 0.05 \text { Group } 4 \text { vs. Groups } 1-3 \text { ). } \\
\text { Indirect costs: } € 9113, € 8638, € 10,001 \text {, and } € 4786 \text { (Groups } 1,2,3 \text {, and } 4 \text { respectively) a }\end{array}$}} \\
\hline & \multicolumn{2}{|c|}{ 4. MTX + INF } & Productivity was hi & hest in $\mathrm{t}$ & s group & & \\
\hline \multicolumn{8}{|c|}{ Observational Trials } \\
\hline Zhang 2008 [24] & Absenteeism, mean & ADA vs. baseline & ND & ND & ND & ND & $\begin{array}{l}\text { Lost productivity costs, past two weeks: } \\
-\$ 57.21 \text { (mean) }\end{array}$ \\
\hline Hone 2013 [26] & $\begin{array}{l}\text { Hours gained/patient } \\
\quad \text { (absenteeism) }\end{array}$ & $\begin{array}{c}\text { ETA baseline vs. } 6 \\
\text { months }\end{array}$ & $\begin{array}{c}71.1 \text { vs. } 63.5 / \\
9.9 \pm 20.1 \text { vs. } 4.4 \pm 16.1\end{array}$ & $\begin{array}{c}7.6 / \\
-3.5 \\
\pm 17.0\end{array}$ & $\begin{array}{c}\mathrm{ND} / \\
(-6.1 ;-1.0)\end{array}$ & $\begin{array}{l}\mathrm{ND} / \\
\mathrm{YES}\end{array}$ & Economic gain/patient: $\$ 1794$ \\
\hline Klimes 2014 [27] & Productivity costs & $\begin{array}{l}\text { Without vs. with } \\
\text { biological } \\
\text { treatment }\end{array}$ & ND & ND & ND & ND & $\begin{array}{l}\text { Friction cost approach: } \\
€ 1304 \text { vs. } € 2090\end{array}$ \\
\hline Tanaka 2018 [28] & Absenteeism & $\begin{array}{c}\text { Baseline vs. week } \\
48\end{array}$ & ND & ND & ND & ND & $\begin{array}{c}\text { Human capital method } \\
\text { (cumulative reduction): } \\
\text { PW: } \$ 9278 \text { (mean) } \\
\text { PTW: } \$ 6480 \text { (mean) } \\
\text { HM: } \$ 5449 \text { (mean) }\end{array}$ \\
\hline \multicolumn{8}{|c|}{ 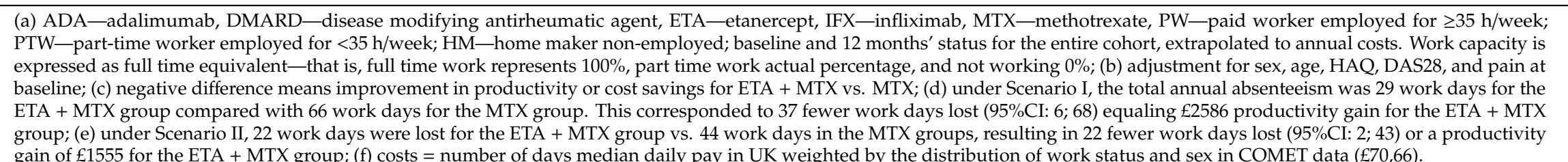 } \\
\hline
\end{tabular}


Table 3. Effect of biological treatment on presenteeism studies.

\begin{tabular}{|c|c|c|c|c|c|c|c|}
\hline Author & Measure & Comparator & Difference & $\Delta$ & $95 \% \mathrm{CI}$ & Significant or Not & Costs \\
\hline \multicolumn{8}{|c|}{ RCT Trial } \\
\hline \multirow{6}{*}{ Anis 2009 [23] } & $\begin{array}{c}\text { WPAI: } \\
\text { Work productivity loss at work (\%) }\end{array}$ & \multirow{6}{*}{ MTX vs. ETA + MTX } & 23.1 vs. 15.6 & -7.5 & $(-11.2 ;-4.2)$ & YES & NA \\
\hline & $\begin{array}{l}\text { WPAI: } \\
\text { Lost work days due to presenteeism }\end{array}$ & & $\begin{array}{l}\text { Scenario I: } 34.0 \text { vs. } 28.6 \\
\text { Scenario II: } 38.9 \text { vs. } 29.7\end{array}$ & $\begin{array}{l}-5.4 \\
-9.3 \\
\end{array}$ & $\begin{array}{c}(-13.5 ; 2.8) \\
(-16.3 ;-2.5)\end{array}$ & $\begin{array}{l}\text { NO } \\
\text { YES }\end{array}$ & $\begin{array}{l}-£ 382 \\
-£ 657\end{array}$ \\
\hline & $\begin{array}{l}\text { WPAI: } \\
\text { Total work productivity loss, days }\end{array}$ & & $\begin{array}{l}\text { Scenario I: } 99.6 \text { vs. } 57.6 \\
\text { Scenario II: } 83.3 \text { vs. } 51.9 \\
\end{array}$ & $\begin{array}{l}-42.0 \\
-31.3 \\
\end{array}$ & $\begin{array}{l}(-69.0 ;-15.7) \\
(-50.2 ;-12.6)\end{array}$ & $\begin{array}{l}\text { YES } \\
\text { YES }\end{array}$ & $\begin{array}{l}-£ 2968 \\
-£ 2212\end{array}$ \\
\hline & $\begin{array}{l}\text { WLQ: work productivity loss at } \\
\text { work (\%) }\end{array}$ & & 6.2 vs. 4.8 & -1.4 & $(-2.1 ;-0.7)$ & YES & NA \\
\hline & $\begin{array}{c}\text { WLQ: } \\
\text { Lost work days due to presenteeism }\end{array}$ & & $\begin{array}{l}\text { Scenario I: } 9.1 \text { vs. } 8.9 \\
\text { Scenario II: } 10.4 \text { vs. } 9.2 \\
\end{array}$ & $\begin{array}{l}-0.3 \\
-1.3 \\
\end{array}$ & $\begin{array}{l}(-2.3 ; 1.8) \\
(-2.8 ; 0.3)\end{array}$ & $\begin{array}{l}\text { NO } \\
\text { NO }\end{array}$ & $\begin{array}{l}-£ 21 \\
-€ 92 \\
\end{array}$ \\
\hline & $\begin{array}{l}\text { WLQ: } \\
\text { Total work productivity loss, days }\end{array}$ & & $\begin{array}{l}\text { Scenario I: } 74.7 \text { vs. } 37.8 \\
\text { Scenario II: } 54.8 \text { vs. } 31.5\end{array}$ & $\begin{array}{l}-36.9 \\
-23.3\end{array}$ & $\begin{array}{l}(-66.9 ;-7.6) \\
(-43.0 ;-4.2)\end{array}$ & $\begin{array}{l}\text { YES } \\
\text { YES }\end{array}$ & $\begin{array}{l}-£ 2607 \\
-£ 1646\end{array}$ \\
\hline \multicolumn{8}{|c|}{ Observational trials } \\
\hline Zhang 2008 [24] & Absenteeism, mean & ADA vs. baseline & $\mathrm{ND}$ & $\mathrm{ND}$ & $\mathrm{ND}$ & ND & $\begin{array}{l}\text { Lost productivity costs, past two weeks: } \\
\qquad \$ 4.48\end{array}$ \\
\hline \multirow[t]{2}{*}{$\underset{[25]}{\text { Augustsson }} 2010$} & \multirow[t]{2}{*}{ Overall } & Unadjusted model & \multicolumn{3}{|c|}{$\begin{array}{l}\text { Improvement: } \\
\text { first year: } 4.2 \mathrm{~h} / \text { week, } \\
\text { thereafter: } 0.5 \mathrm{~h} / \text { week }\end{array}$} & $\begin{array}{l}\text { The productivity gains for } \\
\text { society in patients continuing treatment } \\
\text { would total } € 28,000 \text { over } 5 \text { years. }\end{array}$ & \multirow{2}{*}{$\begin{array}{l}\text { Note that these estimates only apply to } \\
\text { patients who do not discontinue } \\
\text { treatment, a group that may be difficult to } \\
\text { identify before } \\
\text { treatment initiation. }\end{array}$} \\
\hline & & Adjusted model ${ }^{\mathrm{b}}$ & \multicolumn{3}{|c|}{$\begin{array}{l}\text { Improvement: } \\
\text { first year: } 4.1 \mathrm{~h} / \text { week, } \\
\text { thereafter: no change }\end{array}$} & $\begin{array}{l}\text { The productivity gains for } \\
\text { society in patients continuing treatment } \\
\text { would total } € 27,000 \text { over } 5 \text { years. } \\
\text { This corresponds to approximately } 40 \% \text { of } \\
\text { the annual anti-TNF drug cost. }\end{array}$ & \\
\hline Hone 2013 [26] & $\begin{array}{l}\text { Hours gained/patient } \\
\text { (presenteeism) }\end{array}$ & $\begin{array}{l}\text { ETA baseline vs. } 6 \\
\text { months }\end{array}$ & $\begin{array}{c}205.2 \text { vs. } 189.7 / \\
39.7 \pm 24.5 \text { vs. } 24.8 \pm 22.5 \\
\end{array}$ & $\begin{array}{c}15.5 / \\
-13.5 \pm 23.3 \\
\end{array}$ & $\begin{array}{c}\mathrm{ND} / \\
(-17.0 ;-9.9) \\
\end{array}$ & $\begin{array}{l}\mathrm{ND} / \\
\mathrm{YES}\end{array}$ & $\begin{array}{c}\text { Economic gain/patient: } \\
\$ 5328\end{array}$ \\
\hline Tanaka 2018 [28] & Presenteeism & Baseline vs. week 48 & ND & ND & ND & ND & $\begin{array}{c}\text { Human capital method } \\
\text { (cumulative reduction): } \\
\text { PW: \$5836 (mean) } \\
\text { PTW: \$2726 (mean) } \\
\text { HM: NA }\end{array}$ \\
\hline
\end{tabular}

ADA—adalimumab, DMARD—disease modifying antirheumatic agent, ETA—etanercept, IFX—infliximab, MTX—methotrexate, PW—paid worker employed for $\geq 35$ h/week; PTW—part-time worker employed for $<35 \mathrm{~h}$ /week; HM-home maker non-employed; WLQ-Work Limitations Questionnaire; (a) Baseline and 12 months' status for the entire cohort, extrapolated to annual costs. Work capacity is expressed as full time equivalent-that is, full time work represents $100 \%$, part time work actual percentage, and not working $0 \%$; (b) own estimation based on data presented in publication; (c) using the friction cost method for valuation of productivity losses, the infliximab group had borderline higher productivity losses $(€ 14,597 \mathrm{vs} . € 12,018$; adjusted mean difference $€ 2134 ; 95 \% \mathrm{CI}$ : $-284 ; 4535)$, and (as with the human capital method) higher total costs (€42,084 vs. $€ 22,382$; adjusted mean difference $€ 19,090$; $95 \%$ CI: 15,$564 ; 22,252)$ than the conventional treatment group; DMARD—disease-modifying antirheumatic drug. 
Allaart et al. investigated the findings of BeSt trial, in which four treatment strategies were evaluated (Table 1). Patients in groups 3 and 4 were observed with faster improvement in utility measures, though all strategies were comparable at 2 years. In the proportion of patients with initial combination with MTX and IFX, an improvement of four absent hours/week when compared to group 3 was observed at 2 years. It was concluded that quality of life shares a relationship with productivity; a decrease in 0.1 on utility was associated with two less working hours per week [22]. Some doubts have been raised over BeSt trial analyses over baseline differences in productivity [49]. In the BeSt Study utilizing the FCM, overall societal costs were estimated at $€ 19,905$ (seq. monotherapy), $€ 15,926$ (step-up comb. therapy), $€ 17,810$ (initial comb. therapy), and $€ 28,547$ (MTX + INF) ( $p \leq 0.05$ Group 4 vs. Groups 1-3), but total medical costs were estimated at $€ 10,792, € 7288$, $€ 7809$, and $€ 23,761$, respectively, in Groups $1-4$. On a side note, $59 \%$ of patients did not have a job, while cost-effectiveness was only reported for the entire group [22].

Zhang et al. evaluated adalimumab (ADA) and productivity measures at baseline and following 12 weeks of treatment in RA of moderate to severe character. Work productivity outcomes and associated costs were assessed through the health labor questionnaire (HLQ). This entailed a sub-study of the Canadian Adalimumab Clinical Trial (CanAct), in which the economic burden of work productivity loss was determined from a societal perspective. A comparison with regard to treatment response status was performed. No significant effect on employment was observed in short-term, though improvement in absenteeism ( 0.5 work days per 2 weeks) and unpaid work productivity ( 3.5 fewer hours unpaid help per 2 weeks) was observed after 12 weeks. Clinical response was associated with improvements [24].

Klimes et al. performed a cost-of-illness investigation, which included productivity costs for consecutive RA outpatients of productive age. Patients were divided by HAQ scores into groups. Unemployed patients, retired pensioners, and students were excluded. Sick leave days and time on disability pension, both within a maximum friction period, were obtained by providers at month 0 , when functional scores were determined. It was observed that higher HAQ scores are linked to downward trends of sick leave, which may be explained through work status. Higher HAQ scores are associated with an increased proportion of patients on disability pensions. When examining overall annual costs, biological treatment was associated with greater mean (SD) productivity costs of 2090 (1888), while patients without have 1304 (1830) respectively. However, these groups differed in demographic and disease characteristics. Annual mean total (direct and productivity) costs per patient treated with biologicals, without biological treatment, and from the overall cohort were $€ 14,763, € 3559$, and $€ 8882$, respectively [27].

Augustsson et al. reported data from the prospective STURE register, and analyzed the relationship of ETA, infliximab (IFX), and ADA with workforce participation in over 5 years of follow-up. Subjects not participating in workforce, old age and permanent work disability pensioners, and over 55 years of age were not included, while only first treatment period data was considered. The data for employment outcome measures were obtained from questionnaires. Some data was missing, and sample size decreased due to treatment (discontinuation) and management (irregular follow-up) related factors. Conclusions of the associated gains include more hours worked/week in year 1 and annual improvements in years $2-5$ by using TNF-antagonist. Economic gains were projected as close to $40 \%$ of annual anti-TNF drug cost when treatment is continued. However, there was no control group and comparison was based on an assumption that no loss in productivity occurs over 5 years without anti-TNF agents. Potential sources of bias include questionnaire data based on self-reported claims and differential dropout of patients, which limits these findings to patients who continue TNF inhibitors [25].

Hone et al. reported data from an observational, longitudinal study of part/fulltime employed patients with moderate to severe RA commencing ETA. Work productivity and activity impairment questionnaire (WPAI) was administered via telephone communication, while medical chart review was performed only at 6-month timepoint completion. After 6 months, mean (SD) change from baseline for absenteeism was -0.5 (17.0); $95 \%$ CI $-6.1,-1.0$ for all patients, -4.1 (14.2); $95 \%$ CI $-6.5,-1.8$ for 
continuers and insignificant -1.0 (25.9); $95 \%$ CI $-10.3,-8.4$ for discontinuers [26]. Annual economic gains in productivity could compensate the cost of ETA in part or total. Potential bias may be associated with an overestimation through WPAI, as compared to other measuring tools [50], or questionnaire design with attribution and responder bias.

Tanaka et al. published a report from the ANOUVEAU cohort, which was a 48 week observational, multicenter study of ADA among inadequate responders to conventional treatment. Productivity outcomes, including absenteeism and presenteeism, were assessed through validated questionnaires (WPAI/RA), and were significantly improved by administrating ADA. This was observed for different employment status (paid workers, part time, and home makers) when comparing to baseline [28]. Potential limitations include a single study arm, and a comparison of outcomes from baseline.

\subsection{Overview of Indirect Costs}

In the COMET trial, total work productivity loss (the sum of absenteeism and presenteeism) was 42 work days or $£ 2968$ less in the ETA + MTX treatment group compared to MTX under Scenario I, or 31 work days or $£ 2212$ less under Scenario II (when the WPAI was used to estimate the percentage work productivity loss at work, total work productivity loss). When WLQ was used to estimate the percentage work productivity loss at work, total work productivity loss was 37 work days or $£ 2607$ less in the ETA + MTX group than MTX group under Scenario I, or 23 work days or $£ 1646$ less under Scenario II [23].

In the CanAct clinical trial, costs saved by responders were up to CAN $\$ 155.04$ per 2 weeks greater than in nonresponses. In a study by Zhang et al. four measures of presenteeism were compared in patients with osteoarthritis and RA including the HLQ, WLQ, HPQ, and the WPAI. Based on a 2-week follow-up period, the average (SD) number of hours lost was conversion into CAN\$ resulted in average indirect costs over a 2-week period of, respectively, CAN\$30.03, \$83.05, \$284.07, and \$285.10 [24].

Hone et al. projected 12-month gain in work productivity for continuers of ETA at $284.5 \mathrm{~h}$ per patient, equating to $\$ 3233-22,533$ relative to the annual income level. In these employed patients with moderate to severe RA, etanercept significantly decreases overall work and activity impairment, which may compensate a proportion, if not the full cost, associated with treatment $(\$ 20,190)[26]$.

Reports from the ANOUVEAU registry on RA-related productivity loss of Japanese society estimate the impactat $\$ 9.80$ billion. Annual decrease in productivity loss through ADA administration to Japanese RA patients was estimated to be $\$ 3.76$ billion [28].

\section{Discussion}

The socioeconomic impact of RA is substantial, with work disability rate several fold greater than in the general population [51]. Longitudinal data supports the early and progressive impact of RA on work disability over time [52]. Benucci et al. recently discussed the changing structure of RA costs in Italy and how indirect costs consideration is essential for an adequate view of economic disease burden [39]. Furneri et al. indicated that introduction of biologics has significantly raised direct medical costs in a proportion of patients, but at the same time they significantly reduce parameters of disease severity and productivity loss [42]. Trends in RA, for which disability pension has declined in Sweden, may be attributed not only to biologics, but also to more effective treat-to-target strategies. Moreover, a variety of political and demographic factors may also exert a certain effect [53]. Indirect costs as a component of total spending vary by country [54]. The introduction of biosimilars has led to a decrease in public reimbursement, which may lead to greater patient accessibility and more widespread use [55]. Together, these findings substantiate a re-evaluation of the current evidence on biological agent impact on indirect costs, which comprise a major part of RA-related economic burden.

The data analyzed in the current systematic review suggests that biological agents, namely TNF-antagonists, improve indirect costs pertaining to absenteeism and presenteeism measures, which is associated with a varying degree of economic benefit [22-26,28]. Many factors may confound the findings of individual studies, e.g., population characteristics, cost calculation method, and measuring 
instrument, in which none is ideal for quantification of productivity loss [14]. Several instruments are utilized to measure productivity outcomes, however, although findings are usually skewed into one direction, the magnitude of the effect may differ [23]. The data support beneficial economic effects associated with TNF inhibitor effects on absenteeism in RA, particularly at its early stages, though inter-study heterogeneity in populations and outcome measures limits conclusions in general. In 2006, a systematic review of RA impact on workplace productivity reported that scarce data are available for presenteeism [18], which has changed in recent years. However, less reliable data are available for presenteeism and associated economic gains, but they suggest a beneficial effect incurred by biologics. Aside from the lack of standardization, there are other sources of bias to consider. Questionnaire studies are prone to recalland misattribution bias. Baseline rather than head-to-head comparison, substantial missing data or loss to follow-up, and imputation of presenteeism are other potential confounders.

We identified several reviews in our study. Most recently, Verstappen et al. provided an in-depth overview of studies investigating absenteeism and presenteeism, though without an economic focus. The authors discussed that many studies include longstanding RA, in which patients often experienced work loss at inclusion, which may imply a lesser benefit under biological treatment. Work impairment, absenteeism, and work loss were outlined to share a close relationship, where the focus on only one measure of productivity may obscure clinical and economic evaluation. The authors shortly discussed that sick leave, particularly in early RA, may be improved by biologics, though the data for presenteeism is limited [46]. It was also concluded that the economic gain for society and the employer requires further investigation. Data obtained in this systematical review is in line with these conclusions, though it extends these findings to economic evaluation. An earlier systematic review of similar scope on work participation, conducted in 2011, determined that no pooled effect size can be analyzed due to heterogeneity of data [56]. In line with our results, an overall small positive effect on absenteeism and presenteeism depending on the study comparator was reported for almost all of the included studies, though economic projection was not focused upon.

The majority of studies utilize the HCM $[23,24,26,28]$, which carries some inherent weaknesses. However, the FCM also requires consideration of employee replaceability and appropriate friction period. Both approaches may not be easily generalizable. Zhang et al. emphasized that tailoring to individual work and workplace characteristics would improve the projections [57]. In the BeSt trial analyses, the feasibility of initial IFN combination depended on the method of calculation [38]. The value of projections associated with productivity is dependent on the local healthcare system, and how it attributes productivity. Differences of even several fold magnitude can be observed with varying calculation approaches; as follows from a comprehensive review of RA costs in 2009, which reported loss of productivity amounted to $€ 8452$ using HCM compared to $€ 1441$ using FCM [58]. Estimated costs per patient and year in Europe were $€ 15,000$ and $€ 3800$ in Western and Central/Eastern Europe respectively (2008), which underscores the individual healthcare system perspective $[40,58]$. In another review by Lundkvist et al., indirect costs were $€ 16.584$ billion per year in Europe and $€ 8.716$ billion per year in the US. Per patient annual values were quite similar: $€ 4300$ in Europe and $€ 4400$ in the US [59]. In has been discussed that economic analyses also differ in model type and feature, with a subsequent variability in estimates [45]. Prior studies have reported that economic analyses for RA are scarce, whereas indirect costs are a major contributor and their exclusion is a substantial shortcoming $[43,45]$. With a difficulty in direct comparison, applicability to local healthcare systems is limited [45]. In summary, depending on the method of calculation and comparative scenario, biological agents may compensate expenditures.

Drug acquisition costs may be influenced by the introduction of biosimilars on the market and associated price erosion, which may alter the contribution of productivity savings to total costs. Cross country inequities in biological access are still prevalent [60], while the distribution of indirect costs also differs by healthcare [54]. Studies from countries with strict reimbursement and low availability of biological agents may report minor improvements in work productivity. This may refer to patients with advanced disease stages where irreversible disability has occurred, which may obscure the 
beneficial effect of biologics [40]. Some biological drugs have multiple indications in immune mediated inflammatory diseases, which may also improve their cost-efficiency in comorbidity [41]. Fautrel et al. have outlined that although biologics substantially impact work participation, the benefits in patients with more severe and disabling disease are less [40], which unfortunately concerns a considerable proportion of patients encountered in routine practice. Both real-life and trial data are therefore important for decision makers and clinicians alike.

It is necessary to comment on the weaknesses of our study. Incomplete retrieval of records could have occurred due to the adoption of several brand names for biological agents into our search strategy, which may be restricted in certain countries. Comorbidity is prevalent among RA patients, while RA is not the only condition that impacts workplace productivity. Recent reports show that cardiovascular and mental health conditions are among the most common among RA sufferers, in the case of the former they may even convey a difficult-to-control disease profile, while both have been associated with presenteeism, and pose as confounders to our findings [20,61,62]. Depression has also been previously discussed as a particularly difficult confounder when considering productivity outcomes [63]. Moreover, other than DMARD regimens, self-management and non-pharmacological strategies may also impact productivity, which was also not considered in our analyses. We conducted only an analysis of the MEDLINE database, which may not include all relevant reports, while records were considered only in English language, which lead to an exclusion of one study. Furthermore, it should be underlined that the simultaneous use of medicines and effective self-management programs by patients may also affect the results of this study.

\section{Conclusions}

The burden of RA from both a societal and economic standpoint is high. In the majority of studies, data suggests biological treatment may lead to improved absenteeism and presenteeism, though the magnitude of the effect is variable. Associated monetary savings incurred by biologics are reliant on RA patients retaining employment and work ability. There are several other confounders to the conclusions that have to be kept in mind. High prevalence of comorbidities among RA sufferers makes the attribution of workplace impairment to a sole condition difficult, and therefore indirect economic gains associated with biological therapy are arguably tentative. Delineating the impact of RA alone on absenteeism and presenteeism remains particularly difficult with some of the more commonly co-occurring conditions, i.e., depression, which have been previously identified as confounders. Moreover, self-management strategies other than medication with DMARDs may positively influence workplace productivity, and should also be investigated. Real-life data and head-to-head comparisons comparing biologics and the current standards of care with regard to indirect costs are warranted. There are different populations, comparators, productivity measures, and cost models across studies, which makes a direct comparison difficult. Response to biological therapy is another factor to account for, which would require adequate predictors to determine utility among particular patient groups.

Author Contributions: B.B. and M.W. conceived and designed this study; M.W. and P.R.-W. participated in data collection; M.W. and B.B. analyzed, co-wrote, and edited the manuscript. All authors contributed critically to the manuscript.

Funding: This article was funded by Sandoz Poland. Sandoz Poland reviewed and provided feedback on the paper to the authors. The authors had full editorial control of the paper and provided final approval of all content. Systematic review and the analysis of the results were funded by Sandoz Poland. Sandoz Poland covered publication costs. SPEAK/BIO/001/02-2019.

Conflicts of Interest: Bogdan Batko has consulting and speaker fees from AbbVie, Biogen, Egis, MSD, Novartis, Pfizer, Roche, Sandoz, UCB. 


\section{Appendix A}

Table A1. Search strategy.

\begin{tabular}{|c|c|c|}
\hline N. & Query & Items Found \\
\hline$\# 1$ & adalimumab* OR Humira OR (D2E7 AND antibody) OR adalimumab [MeSH] & 6987 \\
\hline \#2 & $\begin{array}{c}\text { etanercept }{ }^{*} \text { OR Enbrel OR Erelzi OR Benepali OR (TNR-001 AND "fusion protein") OR } \\
\text { etanercept [MeSH] }\end{array}$ & 7804 \\
\hline \#3 & tocilizumab* OR RoActemra OR atlizumab OR tocilizumab [MeSH] & 2380 \\
\hline$\# 4$ & certolizumab* OR Cimzia OR (CDP870 OR CDP-870) OR certolizumab [MeSH] & 1072 \\
\hline \#5 & rituximab* OR MabThera OR rituximab $[\mathrm{MeSH}]$ & 19,933 \\
\hline \#6 & anakinra OR Kineret OR anakinra [Mesh] & 5464 \\
\hline \#7 & abatacept OR Orencia OR abatacept [MeSH] & 3353 \\
\hline \#8 & infliximab OR Remicade OR infliximab [MeSH] & 13,165 \\
\hline \#9 & golimumab OR Simponi OR golimumab [MeSH] & 962 \\
\hline \#10 & biologic ${ }^{*}$ OR bio-logic ${ }^{*}$ OR "bio logic*" OR biosimilar* OR bio-similar* or "bio similar*" & $1,735,869$ \\
\hline$\# 11$ & \#1 OR \#2 OR \#3 OR \#4 OR \#5 OR \#6 OR \#7 OR \#8 OR \#9 OR \#10 & $1,776,784$ \\
\hline \#12 & "rheumatoid arthritis" OR RA & 159,750 \\
\hline \#13 & \#11 AND \#12 & 19,542 \\
\hline \#14 & (Indirect OR Productivity) AND (Cost OR Costs OR Cost* OR (Human AND Capital)) & 64,023 \\
\hline \#15 & absenteeism OR presenteeism & 11,562 \\
\hline \#16 & $\begin{array}{c}\text { "human capital method"'" OR HCM OR "'willingness to pay method"'" OR WTP OR } \\
\text { "'"friction cost method"'" OR FCM }\end{array}$ & 15,253 \\
\hline$\# 17$ & \#13 AND (\#14 OR \#15 OR \#16) & 153 \\
\hline
\end{tabular}

Table A2. Risk of bias in randomized controlled trials included in systematic review.

\begin{tabular}{ccc}
\hline Domain & $\begin{array}{c}\text { BeST } \\
\text { Allaart 2007 [22] }\end{array}$ & $\begin{array}{c}\text { COMET } \\
\text { Anis 2009 [2] }\end{array}$ \\
\hline Random sequence generation & Unclear & Low \\
\hline Allocation concealment & Unclear & Low \\
\hline Blinding (participants and personnel) & High & Low \\
\hline Blinding (outcome assessment) & Low & Low \\
\hline Incomplete outcome data & Unclear & Unclear \\
\hline Selective reporting & High & Low \\
\hline Other sources of bias & Unclear & Low
\end{tabular}


Table A3. Risk of bias in observational trials included in systematic review.

\begin{tabular}{|c|c|c|c|c|c|}
\hline Quality Assessment & $\begin{array}{c}\text { Zhang } 2008 \\
{[24]}\end{array}$ & $\begin{array}{c}\text { Augustsson } \\
2010 \text { [25] }\end{array}$ & $\begin{array}{c}\text { Hone } \\
2013 \text { [26] }\end{array}$ & $\begin{array}{l}\text { Klimes } \\
2014 \text { [27] }\end{array}$ & $\begin{array}{c}\text { Tanaka } \\
2018 \text { [28] }\end{array}$ \\
\hline $\begin{array}{l}\text { Case series collected in more than } \\
\text { one centre, i.e., multi-center study }\end{array}$ & Yes & Yes & Yes & No & Yes \\
\hline $\begin{array}{l}\text { Is the hypothesis/aim/objective of } \\
\text { the study clearly described? }\end{array}$ & Yes & Yes & Yes & No & Yes \\
\hline $\begin{array}{l}\text { Are the inclusion and exclusion } \\
\text { criteria (case definition) clearly } \\
\text { reported? }\end{array}$ & Yes/No & Yes/No & Yes & No & Yes \\
\hline $\begin{array}{l}\text { Is there a clear definition of the } \\
\text { outcomes reported? }\end{array}$ & Yes & Yes & Yes & Yes & Yes \\
\hline Were data collected prospectively? & Yes & Yes & Yes & No & Yes \\
\hline $\begin{array}{c}\text { Is there an explicit statement that } \\
\text { patients were recruited } \\
\text { consecutively? }\end{array}$ & Yes & Yes & Yes & Yes & Yes \\
\hline $\begin{array}{l}\text { Are the main findings of the study } \\
\text { clearly described? }\end{array}$ & Yes & Yes & Yes & Yes & Yes \\
\hline $\begin{array}{l}\text { Are outcomes stratified? (e.g., by } \\
\text { disease stage, abnormal test } \\
\text { results, patient characteristics) }\end{array}$ & Yes & Yes & Yes & Yes & Yes \\
\hline
\end{tabular}

\section{References}

1. Cross, M.; Smith, E.; Hoy, D.; Carmona, L.; Wolfe, F.; Vos, T.; Williams, B.; Gabriel, S.; Lassere, M.; Johns, N.; et al. The global burden of rheumatoid arthritis: estimates from the Global Burden of Disease 2010 study. Ann. Rheum. Dis. 2014, 73, 1316-1322. [CrossRef] [PubMed]

2. Batko, B.; Stajszczyk, M.; Świerkot, J.; Urbański, K.; Raciborski, F.; Jędrzejewski, M.; Wiland, P. Prevalence and clinical characteristics of rheumatoid arthritis in Poland: A nationwide study. Arch. Med. Sci. 2019, 15, 134-140. [CrossRef] [PubMed]

3. Rheumatology, 6th ed.; Hochberg, M.C. (Ed.) Mosby/Elsevier: Philadelphia, PA, USA, 2015; ISBN 978-0-323-09138-1.

4. Yang, D.-H.; Huang, J.-Y.; Chiou, J.-Y.; Wei, J.C.-C. Analysis of Socioeconomic Status in the Patients with Rheumatoid Arthritis. Int. J. Environ. Res. Public Health 2018, 15, 1194. [CrossRef] [PubMed]

5. Connolly, D.; Fitzpatrick, C.; O’Toole, L.; Doran, M.; O'Shea, F.; Connolly, D.; Fitzpatrick, C.; O'Toole, L.; Doran, M.; O'Shea, F. Impact of Fatigue in Rheumatic Diseases in the Work Environment: A Qualitative Study. Int. J. Environ. Res. Public Health 2015, 12, 13807-13822. [CrossRef] [PubMed]

6. Sokka, T. Work disability in early rheumatoid arthritis. Clin. Exp. Rheumatol. 2003, 21, S71-S74. [PubMed]

7. McIntosh, E. The cost of rheumatoid arthritis. Br. J. Rheumatol. 1996, 35, 781-790. [CrossRef] [PubMed]

8. Birnbaum, H.; Pike, C.; Kaufman, R.; Maynchenko, M.; Kidolezi, Y.; Cifaldi, M. Societal cost of rheumatoid arthritis patients in the US. Curr. Med. Res. Opin. 2010, 26, 77-90. [CrossRef]

9. Krishnan, E.; Lingala, B.; Bruce, B.; Fries, J.F. Disability in rheumatoid arthritis in the era of biological treatments. Ann. Rheum. Dis. 2012, 71, 213-218. [CrossRef]

10. Pugner, K.M.; Scott, D.I.; Holmes, J.W.; Hieke, K. The costs of rheumatoid arthritis: an international long-term view. Semin. Arthritis Rheum. 2000, 29, 305-320. [CrossRef]

11. Chen, S.-J.; Lin, G.-J.; Chen, J.-W.; Wang, K.-C.; Tien, C.-H.; Hu, C.-F.; Chang, C.-N.; Hsu, W.-F.; Fan, H.-C.; Sytwu, H.-K.; et al. Immunopathogenic Mechanisms and Novel Immune-Modulated Therapies in Rheumatoid Arthritis. Int. J. Mol. Sci. 2019, 20, 1332. [CrossRef]

12. Hammond, A. The use of self-management strategies by people with rheumatoid arthritis. Clin. Rehabil. 1998, 12, 81-87. [CrossRef] [PubMed]

13. Jo, C. Cost-of-illness studies: concepts, scopes, and methods. Clin. Mol. Hepatol. 2014, 20, 327-337. [CrossRef] [PubMed] 
14. Her, M.; Kavanaugh, A. Critical analysis of economic tools and economic measurement applied to rheumatoid arthritis. Clin. Exp. Rheumatol. 2012, 30, S107-S111. [PubMed]

15. Raciborski, F.; Kłak, A.; Kwiatkowska, B. Indirect costs of rheumatoid arthritis. Reumatologia 2015, 53, $268-275$. [CrossRef] [PubMed]

16. Smolen, J.; Aletaha, D. The burden of rheumatoid arthritis and access to treatment: a medical overview. Eur. J. Heal. Econ. 2008, 8, 39-47. [CrossRef]

17. Kobelt, G.; Jönsson, B. The burden of rheumatoid arthritis and access to treatment: outcome and cost-utility of treatments. Eur. J. Heal. Econ. 2008, 8, 95-106. [CrossRef] [PubMed]

18. Burton, W.; Morrison, A.; Maclean, R.; Ruderman, E. Systematic review of studies of productivity loss due to rheumatoid arthritis. Occup. Med. (Chic. Ill). 2006, 56, 18-27. [CrossRef] [PubMed]

19. Li, X.; Gignac, M.A.M.; Anis, A.H. The Indirect Costs of Arthritis Resulting From Unemployment, Reduced Performance, and Occupational Changes While at Work. Med. Care 2006, 44, 304-310. [CrossRef]

20. Goetzel, R.Z.; Long, S.R.; Ozminkowski, R.J.; Hawkins, K.; Wang, S.; Lynch, W. Health, absence, disability, and presenteeism cost estimates of certain physical and mental health conditions affecting U.S. employers. J. Occup. Environ. Med. 2004, 46, 398-412. [CrossRef]

21. Collins, J.J.; Baase, C.M.; Sharda, C.E.; Ozminkowski, R.J.; Nicholson, S.; Billotti, G.M.; Turpin, R.S.; Olson, M.; Berger, M.L. The assessment of chronic health conditions on work performance, absence, and total economic impact for employers. J. Occup. Environ. Med. 2005, 47, 547-557. [CrossRef]

22. Allaart, C.F.; Breedveld, F.C.; Dijkmans, B.A.C. Treatment of recent-onset rheumatoid arthritis: lessons from the BeSt study. J. Rheumatol. Suppl. 2007, 80, 25-33.

23. Anis, A.; Zhang, W.; Emery, P.; Sun, H.; Singh, A.; Freundlich, B.; Sato, R. The effect of etanercept on work productivity in patients with early active rheumatoid arthritis: results from the COMET study. Rheumatology 2009, 48, 1283-1289. [CrossRef]

24. Zhang, W.; Bansback, N.; Guh, D.; Li, X.; Nosyk, B.; Marra, C.A.; Anis, A.H. Short-term influence of adalimumab on work productivity outcomes in patients with rheumatoid arthritis. J. Rheumatol. 2008, 35, 1729-1736.

25. Augustsson, J.; Neovius, M.; Cullinane-Carli, C.; Eksborg, S.; van Vollenhoven, R.F. Patients with rheumatoid arthritis treated with tumour necrosis factor antagonists increase their participation in the workforce: potential for significant long-term indirect cost gains (data from a population-based registry). Ann. Rheum. Dis. 2010, 69, 126-131. [CrossRef]

26. Hone, D.; Cheng, A.; Watson, C.; Huang, B.; Bitman, B.; Huang, X.-Y.; Gandra, S.R. Impact of etanercept on work and activity impairment in employed moderate to severe rheumatoid arthritis patients in the United States. Arthritis Care Res. (Hoboken). 2013, 65, 1564-1572. [CrossRef]

27. Klimeš, J.; Vocelka, M.; Šedová, L.; Doležal, T.; Mlčoch, T.; Petř́́ková, A.; Vlček, J. Medical and Productivity Costs of Rheumatoid Arthritis in The Czech Republic: Cost-of-Illness Study Based on Disease Severity. Value Heal. Reg. Issues 2014, 4, 75-81. [CrossRef]

28. Tanaka, Y.; Yamazaki, K.; Nakajima, R.; Komatsu, S.; Igarashi, A.; Tango, T.; Takeuchi, T. Economic impact of adalimumab treatment in Japanese patients with rheumatoid arthritis from the adalimumab non-interventional trial for up-verified effects and utility (ANOUVEAU) study. Mod. Rheumatol. 2018, 28, 39-47. [CrossRef]

29. Eriksson, J.K.; Karlsson, J.A.; Bratt, J.; Petersson, I.F.; van Vollenhoven, R.F.; Ernestam, S.; Geborek, P.; Neovius, M. Cost-effectiveness of infliximab versus conventional combination treatment in methotrexate-refractory early rheumatoid arthritis: 2-year results of the register-enriched randomised controlled SWEFOT trial. Ann. Rheum. Dis. 2015, 74, 1094-1101. [CrossRef]

30. Birnbaum, H.; Pike, C.; Kaufman, R.; Cifaldi, M. Employer Model of Workplace Impacts of Anti-TNF Therapy for Rheumatoid Arthritis. J. Occup. Environ. Med. 2009, 51, 1167-1176. [CrossRef]

31. DAVIES, A.; CIFALDI, M.A.; SEGURADO, O.G.; WEISMAN, M.H. Cost-Effectiveness of Sequential Therapy with Tumor Necrosis Factor Antagonists in Early Rheumatoid Arthritis. J. Rheumatol. 2009, 36, 16-26. [CrossRef]

32. Gissel, C.; Götz, G.; Repp, H. Cost-effectiveness of adalimumab for rheumatoid arthritis in Germany. Z. Rheumatol. 2016, 75, 1006-1015. [CrossRef] 
33. Kobelt, G.; Jönsson, L.; Young, A.; Eberhardt, K. The cost-effectiveness of infliximab (Remicadeß) in the treatment of rheumatoid arthritis in Sweden and the United Kingdom based on the ATTRACT study. Rheumatology 2003, 42, 326-335. [CrossRef]

34. Kobelt, G. TNF inhibitors in the treatment of rheumatoid arthritis in clinical practice: costs and outcomes in a follow up study of patients with RA treated with etanercept or infliximab in southern Sweden. Ann. Rheum. Dis. 2004, 63, 4-10. [CrossRef]

35. Merkesdal, S.; Kirchhoff, T.; Wolka, D.; Ladinek, G.; Kielhorn, A.; Rubbert-Roth, A. Cost-effectiveness analysis of rituximab treatment in patients in Germany with rheumatoid arthritis after etanercept-failure. Eur. J. Heal. Econ. 2010, 11, 95-104. [CrossRef]

36. Soini, E.; Asseburg, C.; Taiha, M.; Puolakka, K.; Purcaru, O.; Luosujärvi, R. Modeled Health Economic Impact of a Hypothetical Certolizumab Pegol Risk-Sharing Scheme for Patients with Moderate-to-Severe Rheumatoid Arthritis in Finland. Adv. Ther. 2017, 34, 2316-2332. [CrossRef]

37. Valle-Mercado, C.; Cubides, M.-F.; Parra-Torrado, M.; Rosselli, D. Cost-effectiveness of biological therapy compared with methotrexate in the treatment for rheumatoid arthritis in Colombia. Rheumatol. Int. 2013, 33, 2993-2997. [CrossRef]

38. Van den Hout, W.B.; Goekoop-Ruiterman, Y.P.M.; Allaart, C.F.; De Vries-Bouwstra, J.K.; Hazes, J.M.; Kerstens, P.J.S.M.; Van Zeben, D.; Hulsmans, H.M.J.; De Jonge-Bok, J.M.; De Sonnaville, P.B.J.; et al. Cost-utility analysis of treatment strategies in patients with recent-onset rheumatoid arthritis. Arthritis Rheum. 2009, 61, 291-299. [CrossRef]

39. Benucci, M.; Rogai, V.; Atzeni, F.; Hammen, V.; Sarzti-Puttini, P.; Migliore, A. Costs associated with rheumatoid arthritis in Italy: past, present, and future. Clinicoecon. Outcomes Res. 2016, 8, 33-41. [CrossRef]

40. Fautrel, B.; Verstappen, S.M.M.; Boonen, A. Economic consequences and potential benefits. Best Pract. Res. Clin. Rheumatol. 2011, 25, 607-624. [CrossRef]

41. Lapadula, G.; Marchesoni, A.; Armuzzi, A.; Blandizzi, C.; Caporali, R.; Chimenti, S.; Cimaz, R.; Cimino, L.; Gionchetti, P.; Girolomoni, G.; et al. Adalimumab in the Treatment of Immune-Mediated Diseases. Int. J. Immunopathol. Pharmacol. 2014, 27, 33-48. [CrossRef]

42. Furneri, G.; Mantovani, L.G.; Belisari, A.; Mosca, M.; Cristiani, M.; Bellelli, S.; Cortesi, P.A.; Turchetti, G. Systematic literature review on economic implications and pharmacoeconomic issues of rheumatoid arthritis. Clin. Exp. Rheumatol. 2012, 30, S72-S84.

43. Homik, J.E.; Suarez-Almazor, M. An economic approach to health care. Best Pract. Res. Clin. Rheumatol. 2004, 18, 203-218. [CrossRef]

44. Modena, V.; Bianchi, G.; Roccatello, D. Cost-effectiveness of biologic treatment for rheumatoid arthritis in clinical practice: An achievable target? Autoimmun. Rev. 2013, 12, 835-838. [CrossRef]

45. Movik, E. TNF-inhibitors for rheumatic diseases (part 3): Health economics / TNF-hemmere ved revmatiske sykdommer (del 3)/Helseøkonomi; Knowledge Centre for the Health Services at The Norwegian Institute of Public Health (NIPH): Oslo, Norway, 2007.

46. Verstappen, S.M.M. Rheumatoid arthritis and work: The impact of rheumatoid arthritis on absenteeism and presenteeism. Best Pract. Res. Clin. Rheumatol. 2015, 29, 495-511. [CrossRef]

47. Higgins, J.P.T.; Altman, D.G.; Gøtzsche, P.C.; Jüni, P.; Moher, D.; Oxman, A.D.; Savovic, J.; Schulz, K.F.; Weeks, L.; Sterne, J.A.C.; et al. The Cochrane Collaboration's tool for assessing risk of bias in randomised trials. BMJ 2011, 343, d5928. [CrossRef]

48. Appendix 4: Quality assessment for Case Series. Available online: https://www.nice.org.uk/guidance/cg3/ documents/appendix-4-quality-of-case-series-form2 (accessed on 18 July 2019).

49. Boers, M. The cost-utility analysis of the BeSt trial: Is a camel in fact a horse with abnormalities in the distribution of dorsal fat? Comment on the article by van den Hout et al. Arthritis Rheum. 2009, 61, 1616-1617. [CrossRef]

50. Zhang, W.; Monique, A.M.; Beaton, D.; Tang, K.; Anis, A.H. Productivity Loss Due to Presenteeism Among Patients with Arthritis: Estimates from 4 Instruments. J. Rheumatol. 2010, 37, 1805-1814. [CrossRef]

51. Albers, J.M.; Kuper, H.H.; van Riel, P.L.; Prevoo, M.L.; van 't Hof, M.A.; van Gestel, A.M.; Severens, J.L. Socio-economic consequences of rheumatoid arthritis in the first years of the disease. Rheumatology (Oxford). 1999, 38, 423-430. [CrossRef] 
52. Lacaille, D.; Sheps, S.; Spinelli, J.J.; Chalmers, A.; Esdaile, J.M. Identification of modifiable work-related factors that influence the risk of work disability in rheumatoid arthritis. Arthritis Rheum. 2004, 51, 843-852. [CrossRef]

53. Hallert, E.; Husberg, M.; Bernfort, L. The incidence of permanent work disability in patients with rheumatoid arthritis in Sweden 1990-2010: before and after introduction of biologic agents. Rheumatology 2012, 51, 338-346. [CrossRef]

54. Gulácsi, L.; Brodszky, V.; Baji, P.; Kim, H.; Kim, S.Y.; Cho, Y.Y.; Péntek, M. Biosimilars for the management of rheumatoid arthritis: economic considerations. Expert Rev. Clin. Immunol. 2015, 11, 43-52. [CrossRef]

55. Manova, M.; Savova, A.; Vasileva, M.; Terezova, S.; Kamusheva, M.; Grekova, D.; Petkova, V.; Petrova, G. Comparative Price Analysis of Biological Products for Treatment of Rheumatoid Arthritis. Front. Pharmacol. 2018, 9, 1070. [CrossRef]

56. ter Wee, M.M.; Lems, W.F.; Usan, H.; Gulpen, A.; Boonen, A. The effect of biological agents on work participation in rheumatoid arthritis patients: a systematic review. Ann. Rheum. Dis. 2012, 71, 161-171. [CrossRef]

57. Zhang, W.; Anis, A.H. The economic burden of rheumatoid arthritis: beyond health care costs. Clin. Rheumatol. 2011, 30, 25-32. [CrossRef]

58. Franke, L.C.; Ament, A.J.H.A.; van de Laar, M.A.F.J.; Boonen, A.; Severens, J.L. Cost-of-illness of rheumatoid arthritis and ankylosing spondylitis. Clin. Exp. Rheumatol. 2009, 27, S118-S123.

59. Lundkvist, J.; Kastäng, F.; Kobelt, G. The burden of rheumatoid arthritis and access to treatment: health burden and costs. Eur. J. Heal. Econ. 2008, 8, 49-60. [CrossRef]

60. Putrik, P.; Ramiro, S.; Kvien, T.K.; Sokka, T.; Pavlova, M.; Uhlig, T.; Boonen, A. Working Group 'Equity in access to treatment of rheumatoid arthritis in Europe' Inequities in access to biologic and synthetic DMARDs across 46 European countries. Ann. Rheum. Dis. 2014, 73, 198-206. [CrossRef]

61. Dougados, M.; Soubrier, M.; Antunez, A.; Balint, P.; Balsa, A.; Buch, M.H.; Casado, G.; Detert, J.; El-zorkany, B.; Emery, P.; et al. Prevalence of comorbidities in rheumatoid arthritis and evaluation of their monitoring: results of an international, cross-sectional study (COMORA). Ann. Rheum. Dis. 2014, 73, 62-68. [CrossRef]

62. Batko, B.; Urbański, K.; Świerkot, J.; Wiland, P.; Raciborski, F.; Jedrzejewski, M.; Koziej, M.; Cześnikiewicz-Guzik, M.; Guzik, T.J.; Stajszczyk, M. Comorbidity burden and clinical characteristics of patients with difficult-to-control rheumatoid arthritis. Clin. Rheumatol. 2019. [CrossRef]

63. Johnston, D.A.; Harvey, S.B.; Glozier, N.; Calvo, R.A.; Christensen, H.; Deady, M. The relationship between depression symptoms, absenteeism and presenteeism. J. Affect. Disord. 2019, 256, 536-540. [CrossRef] 